Jakub Bornio

Uniwersytet Wrocławski

DOI: 10.19195/2450-274X.2.6

\title{
Kwestia Rzezi Wołyńskiej w kontekście kryzysu ukraińskiego - między rosyjską propagandą, ukraińskim poszukiwaniem tożsamości narodowej a polską racją stanu
}

Abstrakt: Niniejszy artykuł traktuje o Rzezi Wołyńskiej analizowanej w kontekście kryzysu ukraińskiego. Badanie skupia się na interpretacji instrumentalnego wykorzystywania przez Rosję, Ukrainę i Polskę zagadnień związanych z eksterminacją polskiej ludności cywilnej przez ukraińskich nacjonalistów. Opracowanie podzielone zostało na trzy części. Pierwsza odnosi się do polityki propagandowej Federacji Rosyjskiej. Ta część pokazuje w jaki sposób Kreml używa kwestii związanych z Rzezią Wołyńską do tworzenia korzystnej dla siebie narracji. Druga część poświęcona jest próbom budowy ukraińskiej tożsamości narodowej na dziedzictwie ukraińskiego nacjonalizmu. Autor analizuje w niej także konkretne działania elit ukraińskich, związane z tematem artykułu. Trzeci fragment natomiast analizuje sprawę Rzezi Wołyńskiej w oparciu o polską raison d'État. W tej części autor przedstawia nie tylko polskie spojrzenie na Rzeź Wołyńską w kontekście kryzysu ukraińskiego, lecz także odnosi ją do geopolitycznego znaczenia Ukrainy dla Polski. Poszczególne wątki są ze sobą połączone i stanowią spójną całość.

Słowa kluczowe: Rzeź Wołyńska, kryzys ukraiński, propaganda, ukraiński nacjonalizm, polska racja stanu, Ukraińska Powstańcza Armia, Euromajdan

The issue of the Volhynian Slaughter in the context of Ukrainian crisis between Russian propaganda, Ukrainian seeking for the national identity and Polish raison d'État

Abstract: The present article is devoted to the Volhynian Slaughter in the context of Ukrainian crisis. Research focuses on interpretation of intentional using (by Russia, Ukraine, Po- 
land) of issues related to the extermination of Polish civilians carried out by Ukrainian nationalists. The article is divided into three parts. The first part refers to the propaganda policy of the Russian Federation. In this part author presents how the Kremlin uses issues related to the Volhynian Slaughter to create narrative favorable for itself. The second part is devoted to the process of building of Ukrainian national identity on the legacy of Ukrainian nationalism. In this part the author analyses also specific activities of Ukrainian authorities, which are linked to the subject matter of the article. The third part includes analysis of the Volhynian Slaughter in the context of Ukrainian crisis through the prism of Polish raison d'Etat. This part depicts not only the Polish perception of the Volhynian Slaughter but also explains links between subject matter and the geopolitical significance of Ukraine for Poland. All three parts of research are interconnected and belong together.

Keywords: The Volhynian Slaughter, the Ukrainian crisis, propaganda, Ukrainian nationalism, Polish raison d'État, Ukrainian Insurgent Army, the Euromaidan

\section{Wstęp}

Kryzys ukraiński wywołany bezpośrednio wskutek decyzji Wiktora Janukowycza o odstąpieniu Ukrainy od umowy stowarzyszeniowej z Unią Europejską, a będący w rzeczywistości efektem niezadowolenia społecznego wynikłego w głównej mierze z recesji ekonomicznej, w jaką Ukraina weszła w drugiej połowie 2012 r. i idealistycznego przekonania społeczeństwa, że samo związanie się ze strukturami zintegrowanej Europy poprawi kondycję państwa, jest przyczyną największej destabilizacji regionu od momentu upadku dwubiegunowego porządku świata ${ }^{1}$. Wieloaspektowe wydarzenia zapoczątkowane przez spontaniczne, oddolne działania mas społecznych jednoczących się w falach protestów w największych ośrodkach miejskich, głównie zachodniej i centralnej Ukrainy, miały ewolucyjny charakter, który w swoim przebiegu zawierał kolejno fazy protestów (manifestacje prounijne, a następnie antyrządowe), kryzysu politycznego oraz fazę wojny hybrydowej jako finalny i ciągle trwający etap kryzysu. Unikalny charakter wojny hybrydowej, różniący się od klasycznie pojmowanego konfliktu zbrojnego użyciem niekonwencjonalnych środków i działaniami poniżej progu wojny, został dobitnie zaprezentowany podczas toczącego się kryzysu ukraińskiego, a raczej konfliktu rosyjsko-ukraińskiego, m.in. poprzez obecność nietypowych jednostek bojowych („Zielone ludziki”, samodzielnie zawiązane ochotnicze jednostki niepodlegające ośrodkom władzy, ochotnicy obcych narodowości), referenda i plebiscyty samozwańczych republik, aneksję Krymu, prowadzoną na szeroką skalę wojnę informacyjną, ataki cybernetyczne i wiele innych. Ze względu na szerokie spektrum działań podejmowanych przez Kreml i Kijów w ramach toczącego się konfliktu, niektóre aktywności będące elementami wojny hybrydowej swoim zasięgiem wy-

${ }^{1}$ Katalog głównych przyczyn wybuchu kryzysu ukraińskiego jest znacznie szerszy i poza wspomnianymi elementami zawiera m.in. rosyjską presję ekonomiczną i geopolityczną (struktura handlu ukraińsko-rosyjskiego, nowy, bardziej korzystny kontrakt gazowy, długoterminowa pożyczka), presję demokratyczną ze strony Unii Europejskiej (m.in. sprawa Julii Tymoszenko), wszechobecną korupcję czy perspektywę zaplanowanych na 2015 r. wyborów prezydenckich. 
kraczają poza terytorialne granice Ukrainy i Rosji. Idealnym tego przykładem jest wojna informacyjno-propagandowa, która ze względu na doświadczenia historyczne regionu jest silnym narzędziem wpływającym na świadomość społeczną i działania elity rządzącej również w Polsce. Nie bez znaczenia jest tu dostarczająca wojnie propagandowej zasobów polityka historyczna, czego najlepszym przykładem, wykorzystywanym na kanwie kryzysu ukraińskiego, jest okres II wojny światowej, a w szczególności kwestie związane z szeroko zakrojoną kolaboracją ludności ukraińskiej i ukraińskich organizacji zbrojnych z III Rzeszą oraz ich odpowiedzialność za mordy dokonywane w tym okresie na ludności cywilnej. Ze względu na szczególne znaczenie dla bilateralnych stosunków polsko-ukraińskich, diametralnie różne pojmowanie i interpretacje wydarzeń okresu II wojny światowej, jak i ideologii ukraińskiego nacjonalizmu przez polskie, rosyjskie i ukraińskie środowiska, teraźniejszą budowę ukraińskiej tożsamości narodowej, m.in. na dziedzictwie Organizacji Ukraińskich Nacjonalistów i Ukraińskiej Powstańczej Armii ${ }^{2}$, oraz wysoki stopień drażliwości, kwestia Rzezi Wołyńskiej jest jednym z kluczowych elementów polityki historycznej oraz wojny informacyjno-propagandowej, mających wpływ na przebieg kryzysu ukraińskiego.

Niniejszy artykuł podzielony został na trzy części. Pierwsza odnosi się do polityki propagandowej Kremla, druga do prób budowy ukraińskiej tożsamości narodowej na dziedzictwie ukraińskiego nacjonalizmu, trzecia natomiast analizuje kwestię Rzezi Wołyńskiej w oparciu o polską raison d'État. Artykuł ma na celu nie historyczną analizę samej Rzezi Wołyńskiej - czemu zostały już poświęcone liczne opracowania - a interpretację instrumentalnego wykorzystania zagadnień z nią związanych i jej samej poprzez trzy podmioty stosunków międzynarodowych: Rosję, Ukrainę i Polskę. Praca ta jest zaproszeniem do pochylenia się nad problemem czerpania $\mathrm{z}$ tradycji ukraińskiego nacjonalizmu w próbie budowy tożsamości ukraińskiej na „posteuromajdanowskiej” Ukrainie, aktywności ruchów politycznych i społecznych jawnie odwołujących się do dziedzictwa OUN czy działań agend rządowych związanych z tymi zagadnieniami - czemu w opinii autora w polskiej działalności politycznej i naukowej poświęca się zbyt mało uwagi. Celem artykułu jest również osadzenie realiów współczesnej Ukrainy w ramach polskiej racji stanu, ze specjalnym uwzględnieniem kwestii Rzezi Wołyńskiej.

Ze względu na specyfikę kryzysu ukraińskiego - przez co rozumie się m.in. uwidocznioną słabość liberalnego pojmowania systemu międzynarodowego, ciągłą obecność hard power jako determinanta realizacji celów politycznych, konsolidację przekonania o niemożności zagwarantowania bezpieczeństwa przez kraje trzecie i na mocy prawa międzynarodowego ${ }^{3}$ oraz dominującą rolę państw, opartą

${ }^{2}$ Organizacji Ukraińskich Nacjonalistów (Організація Українських Націоналістів) - dalej OUN; Ukraińska Powstańcza Armia (Українська Повстанська Армія) - dalej UPA.

${ }^{3}$ Kazus Memorandum Budapesztańskiego i nierespektowanie przez Rosję Traktatu o Konwencjonalnych Siłach Zbrojnych w Europie. 
na parytecie potencjału gospodarczego i militarnego ${ }^{4}$ - poczynione $\mathrm{w}$ artykule analizy i wnioski oparte są o neorealistyczną teorię stosunków międzynarodowych.

\section{Rzeź Wołyńska a polityka propagandowa Kremla}

Europejskie aspiracje Ukrainy były już przed wybuchem kryzysu poważnym wyzwaniem dla Federacji Rosyjskiej, która postrzega politykę rozszerzeniową Unii Europejskiej i Sojuszu Północnoatlantyckiego w kontekście ekspansji terytorialnej „innymi metodami”. W tym też sensie Kreml nie traktuje i nigdy nie traktował zachodnich struktur jako partnera w rozwiązaniu kryzysu ukraińskiego, ale jako przeciwnika rozgrywającego swoje partykularne interesy kosztem Rosji. Euromajdan, będący symbolem sprzeciwu wobec wstrzymania procesu poszerzania współpracy Ukrainy z Unią Europejską, był więc z rosyjskiej perspektywy wyjątkowo niekorzystnym wariantem wydarzeń, na który Moskwa odpowiedziała skondensowaną ofensywą informacyjną. Kreml w ramach wojny propagandowej, prowadzonej głównie poprzez przekaz medialny, określał manifestacje oraz późniejsze obalenie rządów Janukowycza mianem „faszystowskiego przewrotu”. Retoryka przyjęta przez Rosję zyskała na sile w związku ze znaczną ilością symboliki banderowskiej (czerwono-czarnych flag OUN, UPA, zawołania „Sława Ukrajini! Herojam sława!”), w mniejszym stopniu symboliki nazistowskiej i neonazistowskiej ${ }^{5}$, masowo obalanymi pomnikami Lenina ${ }^{6}$, antyrosyjskim i agresywnym nastawieniem uczestników demonstracji ${ }^{7}$ oraz zaangażowaniem aktywistów organizacji uznanych w przekazie Kremla za ultranacjonalistyczne, a nawet neonazistowskie, takich jak Svoboda czy Prawy Sektor ${ }^{8}$. Co istotne skondensowana propaganda nie miała swojego źródła jedynie w środkach masowego przekazu, ale także w wypowiedziach rosyjskich oficjeli najwyższego szczebla i rosyjskiej legislaturze9. W swoim stanowisku Kreml m.in. przypisywał aktywność snajperów na kijowskim Majdanie antyrządowym uczestnikom zamieszek,

${ }^{4}$ Kazus Formatu Normandzkiego (dominacja państw nad organizacjami międzynarodowymi).

${ }^{5}$ W. Mucha, Krew i Ziemia. O ukraińskiej rewolucji, Warszawa 2014, s. 25-26, 32-33.

${ }^{6}$ RT.com, Protesters topple Lenin monument in Kiev, smash to pieces with hammers, 8.12.2013, http://www.rt.com/news/ukraine-protesters-smash-lenin-913/ (dostęp: 7 sierpnia 2015).

A. Wierzbicka-Miazga, Rosja chce zablokować możliwość dialogu Janukowycza z zachodem, OSW, 11.12.2013, http://www.osw.waw.pl/pl/publikacje/analizy/2013-12-11/rosja-chce-zablokowac-mozliwosc-dialogu-janukowycza-z-zachodem (dostęp: 7 sierpnia 2015).

8 W. Engdahl, US, EU meddling in Ukraine battle, RT.com, 30.01.2014, http://www.rt.com/opedge/us-eu-interference-in-ukraine-402/ (dostęp: 7 sierpnia 2015).

${ }^{9}$ С. Канашевич, Госдума приняла законопроект о запрете бандеровской символики, 21.10.2014, http://top.rbc.ru/politics/21/10/2014/54466850cbb20f85ef0a05ac (dostęp: 7 sierpnia 2015). 
a konkretniej Prawemu Sektorowi ${ }^{10}$. Po uchyleniu przez tymczasowy rząd Arsenji Jaceniuka, w dniu 28 lutego 2014 r., ustawy o zasadach polityki językowej — który to krok przy braku regulacji zastępczych znosił oficjalny status języka rosyjskiego w niektórych obwodach kraju - Kreml wykorzystując nieroztropne działanie gabinetu, podsycał liczne na wschodzie Ukrainy protesty i jawnie krytykował szkodliwe $\mathrm{w}$ ich mniemaniu poczynania Kijowa ${ }^{11}$. W tym okresie w propagandzie rosyjskiej podnoszony był również zarzut, że Ukraina zniosła zakaz propagowania faszyzmu i nazizmu, uchwalając 16 stycznia ustawę traktującą o tradycji walki ukraińskich sił antysowieckich podczas II wojny światowej ${ }^{12}$, co przy silnych związkach ukraińskich jednostek $\mathrm{z}$ nazistowskimi strukturami i specyfice ich działania pozwoliło na łatwą do krzewienia propagandę. Wraz z rozwojem kryzysu ukraińskiego „walka z neonazizmem, banderyzmem i radykalnym nacjonalizmem ukraińskim" stała się jednym z priorytetów rosyjskiej polityki zagranicznej ${ }^{13}$. Jasno sformułowany przekaz miał olbrzymi wpływ na postrzeganie wydarzeń przełomu lat 2013/2014, a w szczególności na wschodniej Ukrainie, charakteryzującej się wysokim odsetkiem mniejszości rosyjskiej, gdzie ludność miała dostęp jedynie do telewizji rosyjskojęzycznej oraz na demograficznie rosyjskim Krymie $^{14}$.

Wraz z rosnącym i nieustającym poparciem polskiego rządu dla Ukrainy w jej konflikcie z Rosją oraz europejskich aspiracji Kijowa, wzrastała również informacyjno-propagandowa działalność Kremla na polu bilateralnych stosunków polsko-ukraińskich, co istotne - uwzględniająca kwestię Rzezi Wołyńskiej. Znajduje to swoje potwierdzenie w Raporcie z działalności Agencji Bezpieczeństwa Wewnętrznego w 2014 r., który ze względu na jego charakter należy interpretować nie tylko jako źródło informacji, ale także jako działalność kontrwywiadowczą samą w sobie. „W wyniku działań operacyjno-rozpoznawczych realizowanych w 2014 r. kontrwywiad Agencji Bezpieczeństwa Wewnętrznego potwierdził utrzymywanie się wysokiego poziomu aktywności rosyjskich służb wywiadowczych na kierun-

${ }^{10}$ Вести.Ru, на Майдане работали снайперы „Правого сектора”, 30.03.2014, http://www. vesti.ru/doc.html?id=1426836 (dostęp: 7 sierpnia 2015); W październiku 2015 r. nowe światło na sprawę rzuciła Prokuratura Generalna, która na wniosek Sądu Rejonowego w Kijowie przeszukała mieszkania trzech działaczy partii Svoboda, w tym lokal lidera ugrupowania Oleksandra Sycza, powodem było podejrzenie nielegalnego użycia broni przez członków partii podczas wydarzeń 20 lutego 2014 r. W sprawie tej nie należy wykluczać wątku walki wewnątrzpolitycznej i chęci zmarginalizowania partii Svoboda. Źródło: О. Сич, Post Facebook, 13.10.2015, https://www.facebook.com/sych.olexander/posts/10208340991381816?pnref=story (dostęp: 30 grudnia 2015).

11 Ibidem.

12 T.A. Olszański, Nowy rząd Ukrainy: stabilizacja mimo przeszkód, OSW, 5.03.2014, http:// www.osw.waw.pl/pl/publikacje/analizy/2014-03-05/nowy-rzad-ukrainy-stabilizacja-mimo-przeszkod (dostęp: 7 sierpnia 2015).

${ }_{13}$ Novorossia Today, Fighting against Neo-Nazism one of Russia's foreign policy priorities diplomat, 10.07.2015, http://novorossia.today/fighting-against-neo-nazism-one-of-russia-s-foreign-policy-priorities-diplomat/ (dostęp: 7 sierpnia 2015).

${ }_{14}$ T.A. Olszański, Koniec reżimu Janukowycza, OSW, 26.02.2014, http://www.osw.waw.pl/pl/ publikacje/analizy/2014-02-26/koniec-rezimu-janukowycza (dostęp: 7 sierpnia 2015). 
ku polskim. Przedsięwzięcia tych służb były uwarunkowane m.in. konfliktem na Ukrainie i zostały podporządkowane strategii propagandowej władz na Kremlu. Charakteryzowały się one wykorzystywaniem różnorodnych metod pracy. Ukierunkowane były m.in. na dyskredytację stanowiska Polski i innych państw członkowskich NATO w kwestii kryzysu ukraińskiego, a także na akcentowanie polsko-ukraińskich skomplikowanych doświadczeń historycznych w celu wywoływania antagonizmów pomiędzy społeczeństwami obu tych krajów. [...] Do realizacji tego typu przedsięwzięć Rosjanie wykorzystywali zarówno rosyjskie media, jak i obywateli RP reprezentujących prorosyjską postawę i w niektórych przypadkach opłacanych przez instytucje Federacji Rosyjskiej"15. Swoją politykę propagandową Kreml prowadził również poprzez kształtowanie prorosyjskich i antyukraińskich nastrojów za pomocą blogów, portali internetowych i serwisów informacyjnych. Aktywności takie polegały głównie na wykorzystywaniu działających na zlecenie Moskwy osób lub tzw. pożytecznych idiotów do zamieszczania pożądanych opinii i komentarzy w różnego rodzaju serwisach ${ }^{16}$. Przy czym nie należy interpretować każdej opinii krytycznej wobec poczynań Kijowa jako głosu inspirowanego działaniami Moskwy. Tak kształtowana wojna propagandowa Kremla, silnie akcentująca kwestię ludobójstwa ukraińskiego dokonanego na polskich (ale także rosyjskich, żydowskich, ukraińskich, ormiańskich i innych) mieszkańcach Kresów Wschodnich miała za zadanie wywołanie spadku poparcia społecznego wobec przychylnych Kijowowi działań rządu RP, co za tym idzie - uzyskanie korzystnego dla Moskwy stanowiska elit politycznych i opiniotwórczych oraz, co zostało wspomniane wcześniej, ożywienie wrogich stosunków między narodami. Dobitnym przykładem zmiany retoryki wydaje się być postawa Pawła Kukiza kandydata na prezydenta RP w wyborach z 2015 r. (ponad 20\% poparcia), który do pewnego momentu intensywnie wyrażał swoje poparcie dla fali protestów i prozachodniej drogi obranej przez Ukrainę, by w okresie późniejszym z tego poparcia się wycofać. „Kiedy zobaczyłem, [...] że my rzeczywiście bardzo mocno angażujemy się też duchowo, emocjonalnie w sprawy ukraińskie, a teraz przy okazji 106 rocznicy urodzin Stefana Bandery organizowane są parady we Lwowie i Kijowie banderowców i nie ma absolutnie żadnego stanowiska władz ukraińskich... [...] Nie ma takiej możliwości, żeby w tej sytuacji dawać całego siebie komuś kto uważa, że ich bohaterem narodowym jest morderca Polaków" ${ }^{17}$. Mimo że zmiana retoryki była najprawdopodobniej formą sprzeciwu wobec przejawów rozwijającego się ukraińskiego kultu Bandery i jawnego czerpania z tradycji ukraińskiego nacjonalizmu przez nowe elity rządzące, nie należy przy okazji omawiania postawy

${ }^{15}$ Agencja Bezpieczeństwa Wewnętrznego, Raport z działalności Agencji Bezpieczeństwa Wewnętrznego w 2014r., Warszawa 2015, http://www.abw.gov.pl/pl/pobierz/raporty/575, Raporty. html (dostęp: 8 lutego 2015).

${ }_{16}$ Ibidem.

${ }_{17}$ Portal Telewizji Republika, Republika na żywo - Paweł Kukiz, 18.02.2015, https://www. youtube.com/watch?v=L0LQbfLbO4E (dostęp: 8 lutego 2015). 
Kukiza bagatelizować aspektu propagandy rosyjskiej, która w związku z chęcią realizacji partykularnych celów polityki informacyjnej wykorzystywała tego typu wypowiedzi w rosyjskim przekazie medialnym ${ }^{18}$.

O wspomnianej wcześniej zależności społeczeństwa i kształtowanych jego nastrojami działaniach politycznych w kontekście rozwijającego się kultu UPA wypowiedział się ówczesny kandydat na prezydenta, a dzisiejszy prezydent RP - Andrzej Duda. Zapytany podczas jednego z wywiadów czy Polska, w osobie prezydenta, powinna zachować się stanowczo wobec jawnych i nader ostentacyjnych aktów gloryfikacji zbrodniarzy z UPA przez władze w Kijowie, odpowiedział twierdząco, dodając, że „jeżeli Ukraina będzie chciała mieć z nami dobre relacje, dobre relacje także z polskim społeczeństwem, bo głos społeczeństwa jest niezwykle w tych sprawach istotny [...] to musi prowadzić taką politykę, która prowadzi do pojednania narodów, a nie do pogłębiania istniejących animozji. Prawda historyczna jest taka, że setki tysięcy Polaków zostało zamordowanych na Ukrainie i gloryfikowanie tych, którzy ich zamordowali jest absolutnie działaniem, które nie zmierza w kierunku poprawy stosunków z Polską. [...] Uważam, że trzeba prowadzić uczciwą politykę historyczną także pomiędzy państwami”'19. Owa zależność polityków od poparcia społecznego, na które wpływ ma przecież propaganda Kremla, jest niezwykle istotnym elementem oddziaływującym na polityczne i społeczne relacje polsko-ukraińskie osadzone w realiach kryzysu ukraińskiego. Dlatego wszelkie działania ze strony polskiej w odniesieniu do tego problemu muszą być podejmowane z należytym przygotowaniem, mając na uwadze złożoną specyfikę problemu, o czym będzie mowa w części poświeconej polskiej racji stanu.

Ze względu na wizerunek Polski jako głównego sprzymierzeńca „pomajdanowskiej Ukrainy", kwestia ukraińskich mordów z okresu II wojny światowej na polskich mieszkańcach Kresów Wschodnich w rosyjskim przekazie medialnym była podnoszona nader często. Sytuacja taka miała miejsce m.in. w październiku 2014 r., kiedy to przed kijowskim parlamentem miejsce miała wielotysięczna demonstracja, głównie członków Prawego Sektora i Svobody domagających się przyznania statusu weteranów wojennych dla „nacjonalistycznych partyzantów walczących po stronie Nazistów" ${ }^{20}$ w kwietniu 2015 r., przy okazji wizyty prezydenta Bronisława Komorowskiego na Ukrainie (co ważne - w przekazie zabrakło informacji

18 RussiaToday.com, Кандидат в президенты Польши Павел Кукиз заявил, что нельзя поддерживать героизирующих Бандеру, 18.02.2015, http://russian.rt.com/article/75112 (dostęp: 8 sierpnia 2015).

19 B. Kotowska, Kandydat na prezydenta Andrzej Duda w TV Republika „nie boję się wyzwań", 14.05.2015, https://www.youtube.com/watch?t=435\&v=jAkaIHTZ1Ko (dostęp: 8 sierpnia 2015).

${ }^{20}$ RussiaToday.com, Dozens hurt and arrested after Ukrainian nationalists attack parliament, 12.10.2014, http://www.rt.com/news/195796-nationalists-protest-kiev-ukraine/ (dostęp: 8 sierpnia 2015). 
o Wielkim Głodzie oraz Zbrodni Katyńskiej) $)^{21}$ i uchwalonych tego samego dnia ustaw „dekomunizacyjnych”, kontrowersyjnych ze względu na swój częściowo probanderowski charakter ${ }^{22}$. Za ostatni z przytoczonych tu przykładów wpisujących się $\mathrm{w}$ omawiany nurt przekazu medialnego może posłużyć fragment programu wyemitowanego na antenie Russia Today, w którym to dyskutowano z zaproszonym specjalistą na temat spodziewanych reakcji Warszawy i domniemanych obaw Polski wobec obecności prawicowych i neonazistowskich ekstremistów ${ }^{23}$.

Ciekawym przykładem użycia wypowiedzi przedstawicieli elit w celach propagandowych jest wywiad dla „Dziennika Gazety Prawnej”, udzielony przez generała w stanie spoczynku, Wiceministra Obrony Narodowej w resorcie Tomasza Siemoniaka, Waldemara Skrzypczaka ${ }^{24}$. Wywiad opublikowany kilka dni po uchwaleniu przez Werchowną Radę wspomnianych wyżej ustaw stał się podwaliną do akcentowania kwestii Rzezi Wołyńskiej w kontekście kryzysu ukraińskiego ${ }^{25}$. Sprawa Rzezi Wołyńskiej stała się bezsprzecznie jednym z instrumentów Moskwy, używanym do osiągania w ramach wojny propagandowej - będącej częścią konfliktu rosyjsko-ukraińskiego - swoich partykularnych interesów. Częste akcentowanie ludobójczych metod „walki” i nazistowskich konotacji ukraińskich ruchów nacjonalistycznych okresu II wojny światowej, w połączeniu z jawną gloryfikacją społeczną i polityczną tychże ruchów oraz współczesną obecnością organizacji czerpiących z ideologii OUN i UPA, napędza kremlowską machinę propagandową. Działania Moskwy w tym zakresie skierowane są głównie do obywateli Polski i ludności zamieszkującej wschodnie prowincje Ukrainy. Za swój cel Moskwa obiera przede wszystkim ożywienie antagonizmów pomiędzy Polską i Ukrainą, znaczne obniżenie poparcia polskiego społeczeństwa i elit politycznych dla działań Kijowa oraz lansowanie swojej wizji historii. Niewykluczone, że w ramach szeroko zakrojonej polityki historycznej Kreml obiera za swój cel przesunięcie części odpowiedzialności za zbrodnie na ludności polskiej na stronę ukraińską, mowa tu m.in. o Operacji polskiej NKWD z lat 1937-1939 i innych rosyjskich zbrodniach na narodzie polskim. Działania skierowane do rosyjskojęzycznej ludności wschodniej Ukrainy mają natomiast za zadanie podsycać sprzeciw wobec „faszystowskiego przewrotu” i powstałego w jego konsekwencji nowego, ukraińskiego ładu politycznego, ideologicznie zbliżyć społeczeństwo Donbasu do Rosji i nadać legitymację dla dążeń separatystycznych.

${ }^{21}$ RussiaToday.com, History lesson? Poroshenko says 'Hitler \& Stalin started WWII, wanted to divide Europe', 10.04.2015, http://www.rt.com/news/248409-poroshenko-wwii-stalin-hitler/ (dostęp: 8 sierpnia 2015).

${ }^{22}$ RussiaToday.com, 'Result of Maidan - revival of Nazism in Ukraine', 10.04.2015, http:// www.rt.com/op-edge/248497-ukraine-law-fascists-nazi-ww2/ (dostęp: 8 sierpnia 2015).

${ }^{23}$ Ibidem.

${ }^{24}$ M. Rigamonti, Ze mnie dupa nie polityk, Wywiad z gen. Waldemarem Skrzypczakiem, „Dziennik Gazeta Prawna”, 17.10.2015, nr 74 (3967).

${ }^{25}$ RussiaToday.com, Polish general 'calls back support' of Ukraine over nationalist glorification, 18.10.2015, http://www.rt.com/news/250905-polish-general-rejects-ukrane/ (dostęp: 8 sierpnia 2015). 


\section{Rzeź Wołyńska a ukraińskie poszukiwanie tożsamości narodowej}

Kwestia ukraińskiej tożsamości narodowej jest problemem niezwykle złożonym, wynikającym z „młodości” państwa, problemów natury wielonarodowościowej, wewnętrznego rozdarcia ideologicznego, wysokiej podatności państwa na czynniki zewnętrzne, wieloaspektowej destabilizacji, ubogich zasobów do budowy więzi historycznej i kulturowej oraz wielu innych. Dodatkowa trudność w kształtowaniu owej tożsamości wynika $\mathrm{z}$ faktu, że proces ten zachodzi na bieżąco i prowadzony jest w obliczu konfliktu z Rosją. Zapewne znaczącym problemem w procesie kształtowania ukraińskiej tożsamości narodowej jest również kwestia Rzezi Wołyńskiej. Fakt ten ma związek z chęcią oparcia ukraińskiej świadomości i więzi historycznej na podwalinach walki „narodowowyzwoleńczej” prowadzonej przez struktury OUN i UPA, głównych sprawców Rzezi Wołyńskiej. Znajduje to swoje odzwierciedlenie w nastrojach społecznych, zachowaniu elit politycznych, legislaturze i wszechobecnej (głównie na zachodzie kraju) symbolice banderowskiej, jednak należy odnotować fakt, że ruchy nacjonalistyczne okresu II wojny światowej są nie jedynym, ale jednym z kilku budulców nowej tożsamości ${ }^{26}$. Do poprawnego postrzegania tej kwestii niezbędne jest zaznaczenie, że ukraiński mit „walki narodowowyzwoleńczej” za swojego głównego przeciwnika uznaje sowiecką Rosję oraz w dużej mierze traktowany jest jako ruch antykomunistyczny, co idealnie wpisuje się w potrzeby skomplikowanej sytuacji geopolitycznej kraju. Co więcej świadomość o walce oddziałów UPA z „polskim okupantem” — jak zwykło się nazywać II Rzeczpospolitą w retoryce banderowskiej - i mordach na ludności cywilnej praktycznie nie istnieje. Jest to skutkiem m.in. braku działań elit politycznych, skupionych na poszerzaniu tej sfery świadomości historycznej - co w związku z obecną sytuacją wydaje się być zrozumiałe - działalności władzy radzieckiej, która „starannie dbała o filtrowanie pamięci historycznej unikając przypominania o najostrzejszych konfliktach polsko-ukraińskich" 27 i niskiego poziomu wiedzy historycznej w ogóle.

Wspomniane wcześniej rozdarcie ideologiczne kraju znajduje swoje odzwierciedlenie $\mathrm{w}$ nastrojach społecznych związanych m.in. z pomysłem na postmajdanowski kształt Ukrainy czy jej miejsce w regionie, ale w kwestii najbardziej nas interesującej wiąże się $z$ diametralnie różnym postrzeganiem OUN i UPA na wschodzie - gdzie organizacje są pojmowane jako faszystowskie - i zachodzie

${ }^{26}$ W katalog budulców nowej tożsamości można włączyć m.in. ikony literatury ukraińskiej Tarasa Szewczenkę i Iwana Franko, historyczną kozaczczyznę czy bohaterów tzw. Niebiańskiej Sotni.

${ }^{27}$ J. Hrycak, Jeszcze raz o stosunku Ukraińców do Polaków (z Rosja w tle), [w:] idem, Nowa Ukraina. Nowe Interpretacje, Wrocław 2009, s. 240. 
kraju, gdzie z kolei przypisuje się im status bohaterów ${ }^{28}$. Przy czym należy zaznaczyć, że opinie gloryfikujące wspomniane struktury mają charakter dominujący. Widać to po ciągle wzrastającym poparciu dla ugrupowań politycznych jawnie odwołujących się do spuścizny banderyzmu ${ }^{29}$. Zgodnie z sondażem przeprowadzonym przez Kijowski Międzynarodowy Instytut Socjologii, na dzień 15 lipca 2015 r. ugrupowania te mogły liczyć łącznie na 19,5\% poparcia społecznego, co stanowiło wzrost $\mathrm{w}$ porównaniu $\mathrm{z}$ przeprowadzonymi w ubiegłym roku wyborami o $5,5 \%{ }^{30}$. W analogicznym badaniu we wrześniu $2015 \mathrm{r}$. partie te uzyskały $17 \%$ poparcia ${ }^{31}$. O próbach budowy tożsamości na bazie ruchów nacjonalistycznych i przywiązaniu do nich społeczeństwa świadczy również mnogość symboliki banderowskiej występująca w zachodnich regionach kraju. Czerwono-czarne flagi traktowane są miejscami na równi z oficjalnymi barwami Ukrainy, a znaleźć je można na budynkach administracji publicznej, cmentarzach, rondach, domach mieszkalnych czy za szybami aut. Nie inaczej jest z obrazami z wizerunkiem Stefana Bandery, które bez przeszkód można nabyć w księgarniach i innych punktach sprzedaży. W odniesieniu do budowy tożsamości narodu ukraińskiego na podwalinach ideologii ukraińskiego nacjonalizmu i analizując problem z perspektywy bilateralnych stosunków na linii rząd-społeczeństwo, możemy mówić o występowaniu sprzężenia zwrotnego, charakteryzującego się następującą zależnością: preferencje elektoratu wpływają bezpośrednio na zachowania elit politycznych, wymuszając na nich określone działania, ale elity te również inspirują naród do aktywności i gestów poparcia dla działań reżimu.

O ile społeczeństwo, co zostało zaznaczone wcześniej, nie posiada pełnej świadomości historycznej, o tyle ciężko o to samo podejrzewać elity polityczne kraju, które po części w odpowiedzi na zapotrzebowanie elektoratu, a po części z własnych pobudek budują tożsamość narodową w oparciu o ruchy nacjonalistyczne. Żołnierze Ukraińskiej Powstańczej Armii są w przekazie politycznym kreowani na reprezentujących postawę heroiczną patriotó $w^{32}$ i bohaterów $w^{33}$. Spójne z ową narracją są również akty prawne i obchody wydarzeń okolicznościowych. Jawnym tego przykładem jest proklamowanie w miejsce Dnia Obrońcy Ojczyzny świę-

${ }^{28}$ K. Wężyk, Kresy. Dla nas piekło, dla was raj. Rozmowa z Jarosławem Hrycakiem, 25.07.2015, http://wyborcza.pl/magazyn/1,147225,18418145,kresy-dla-nas-pieklo-dla-was-raj-rozmowa-z-jaroslawem.html (dostęp: 9 sierpnia 2015).

${ }^{29}$ Prawy Sektor, Ogólnoukrainskie Zjednoczenie „Svoboda”, Partia Radykalna Ołeha Laszki.

${ }^{30}$ KIIS, SOCIO-POLITICAL SITUATION IN UKRAINE: JULY 2015, 20.07.2015, http://www. kiis.com.ua/?lang=eng\&cat=reports\&id=540\&page $=1$ (dostęp: 9 sierpnia 2015).

${ }^{31}$ KIIS, SOCIO-POLITICAL SITUATION IN UKRAINE: SEPTEMBER 2015, 5.10.2015, http:// www.kiis.com.ua/?lang=eng\&cat=reports\&id=548\&page=1 (dostęp: 30 grudnia 2015).

${ }^{32}$ M. Babiak, Poroshenko: 'UPA are heroes', will consider giving veteran legal status, Euromaidan Press, 26.09.2014, http://euromaidanpress.com/2014/09/26/poroshenko-to-consider-giving-upa-veterans-legal-status/ (dostęp: 9 sierpnia 2015).

33 Украинская правда, Яценюк о Бандере: это наши герои, 6.11.2012, http://www.pravda. com.ua/rus/news/2012/11/6/6976794/ (dostęp: 9 sierpnia 2015). 
ta wojskowego zwanego Dniem Obrońcy Ukrainy, które zgodnie z decyzją Petra Poroshenki ma być obchodzone 14 października, w dniu utworzenia Ukraińskiej Powstańczej Armii. Działanie te poza uczczeniem zbrojnego ramienia banderowców niosło za sobą dekomunizacyjną wartość dodaną, związaną ze zniesieniem mającego komunistyczny rodowód dnia Obrońcy Ojczyzny ${ }^{34}$. Kolejną próbą uregulowania kwestii tożsamościowych była seria wspomnianych wcześniej aktów prawnych, ustanowionych 9 kwietnia 2015 r., dotyczących polityki historycznej i tożsamościowej. Pomimo jawnie dekomunizującego charakteru ustawy zawierały również regulacje dotyczące uczestników walk o niezależność Ukrainy. Ustawa o numerze 2538-1 zawierała spis organizacji z okresu 1917-1991, których członkowie są uważani za bojowników o niepodległość, włączając w nie OUN i UPA. Dodatkowo uznano przyznawane w UPA stopnie wojskowe i odznaczenia. Ustawa niewątpliwie wpisała się w widoczny w owym okresie trend „dowartościowania tradycji walki o niepodległość Ukrainy w ogóle, a walki UPA (przede wszystkim przeciw Związkowi Sowieckiemu) w szczególności” ${ }^{35}$. Co ważne ustawa traktowała również o penalizacji „zaprzeczania faktu legalności walki o niezależność Ukrainy w XX wieku, co może być w przyszłości wykorzystywane w celu hamowania krytycznej refleksji nad »czarnymi kartami« ukraińskiego ruchu niepodległościowego, w tym dokonanym przez UPA ludobójstwem Polaków na Wołyniu i w Galicji Wschodniej" ${ }^{36}$. Ponadto omawiane ustawy nakładają na państwo obowiązek zwiększenia wysiłków na rzecz propagowania wiedzy o ukraińskich ruchach niepodległościowych $\mathrm{w} X X \mathrm{X} \mathrm{w}^{37} \mathrm{Za}$ ostatni omawiany tu przykład gloryfikacji tradycji walki niepodległościowej posłużyć może uczczenie w ukraińskim parlamencie minutą ciszy Romana Szuchewycza ${ }^{38}$, generała i naczelnego dowódcy Ukraińskiej Powstańczej Armii w sposób bezpośredni odpowiedzialnego za Rzeź Wołyńską.

Ze względu na ubogie zasoby do budowy tożsamości historycznej oraz fakt, że wydarzenia XX w., a w szczególności II wojny światowej oddziaływają najsilniej na świadomość obecnie żyjącej ludności, budowa tożsamości narodowej na kanwie ruchów nacjonalistycznych wydaje się być jedyną możliwą alternatywą dla Kijowa. Fakt, że historycznie częściowo, a w obecnie postrzeganym micie prawie wyłącznie walka wyzwoleńcza łączona jest $\mathrm{z}$ uniezależnieniem się od imperialistycznej Rosji, stanowi w obecnej sytuacji geopolitycznej niezwykle cenną wartość dodaną

34 PolskieRadio.pl, Kijów ustanawia Dzień Obrońcy Ukrainy w dniu święta UPA. Putin oburzony, 14.10.2014, http://www.polskieradio.pl/5/3/Artykul/1258963,Kijow-ustanawia-Dzien-Obroncy-Ukrainy-w-dniu-swieta-UPA-Putin-oburzony (dostęp: 9 sierpnia 2015).

35 T.A. Olszański, Ukraina: ambitne ustawy dekomunizacyjne, OSW, 15.04.2015, http://www. osw.waw.pl/pl/publikacje/analizy/2015-04-15/ukraina-ambitne-ustawy-dekomunizacyjne (dostęp: 9 sierpnia 2015).

36 Ibidem.

37 Ibidem.

38 Kanał Youtube Николай Фадеев, Рада почтила минутой молчания Шухевича, https:// www.youtube.com/watch?v=LObfl9QSbOw (dostęp: 30 grudnia 2015). 
i stanowi przeciwwagę dla rosyjskiej propagandy. Obrana strategia jest również wynikiem dużej presji społecznej, a przede wszystkim radykalnych organizacji, ruchów i partii politycznych. $Z$ tej perspektywy w celu ujarzmienia ekstremistycznych nastrojów społecznych część elektoratu związanego ideowo z banderyzmem jest poprzez działania gloryfikujące ruchy nacjonalistyczne zagospodarowywana przez ugrupowania mniej radykalne. Należy jednak pamiętać, że na tak obranej przez Kijów drodze poza działaniami propagandowymi ze strony Kremla stoją inne przeszkody. Jawnie prounijne aspiracje i budowa tożsamości narodowej na spuściźnie ideologicznej organizacji zbrodniczych są sprzeczne. Zostało to zaznaczone już w 2010 r., kiedy to Parlament Europejski wyraził „głębokie ubolewanie” z powodu przyznania Stefanowi Banderze tytułu bohatera Ukrainy ${ }^{39}$. Mimo iż perspektywa ukraińskiego członkostwa w Unii Europejskiej jest bardzo odległa, należy pamiętać, że pewne procesy wynikłe z kształtowania polityki historycznej i tożsamościowej są bardzo trudno - jeżeli w ogóle — odwracalne i co za tym idzie przewartościowanie ideologii zakorzenionych w społeczeństwie nie będzie łatwe. Kolejnym problemem dla Ukrainy mogą okazać się zmiany polityczne w Polsce, zarówno te prezydenckie, jak i parlamentarne. Dotychczasowa polityka Warszawy prowadzona przez rządy Platformy Obywatelskiej, tłumaczona pragmatyzmem, charakteryzowała się brakiem reakcji, a nawet ignorancją wszelkich działań Kijowa dotyczących polityki historycznej. Z przedwyborczych zapowiedzi prezydenta Andrzeja Dudy wynikało, że retoryka ta zostanie najprawdopodobniej zmieniona, a kwestie pamięci historycznej będą podnoszone w kontaktach z Kijowem o czym szerzej poniżej.

\section{Kwestia Rzezi Wołyńskiej w kontekście kryzysu ukraińskiego a polska racja stanu}

Oparta na demokratycznych wartościach oraz stabilna politycznie i gospodarczo Ukraina leży bezsprzecznie w żywotnym interesie Rzeczypospolitej Polskiej. Ma to swoje uzasadnienie przede wszystkim w konieczności podniesienia stanu bezpieczeństwa narodowego związanego ze stabilizacją regionu, ale również w chęci poszerzania stosunków gospodarczych przekładających się na wymierne korzyści ekonomiczne. Analizując sytuację geopolityczną oraz opierając się na doświadczeniu historycznym, prorosyjska Ukraina nie mieści się z pewnością w katalogu uwarunkowań międzynarodowych, zgodnych z polską racją stanu. Co więcej, jak zauważa profesor Bogumił Grott, „stanowczo niedobrą dla nas jest i druga wersja możliwej sytuacji tj. Ukraina zorganizowana przez ukraiński szowinistyczny nacjonalizm, gdyby ten uzyskał w kraju nad Dnieprem przewagę i stał

${ }^{39}$ European Parliament, European Parliament resolution of 25 February 2010 on the situation in Ukraine, 25.02.2010, http://www.europarl.europa.eu/sides/getDoc.do?pubRef=-//EP//TEX$\mathrm{T}+\mathrm{TA}+\mathrm{P} 7-\mathrm{TA}-2010-0035+0+\mathrm{DOC}+\mathrm{XML}+\mathrm{V} 0 / / \mathrm{EN}$ (dostęp: 10 sierpnia 2015). 
się czynnikiem determinującym jego tożsamość" ${ }^{40}$. Pewne obawy może nieść również taka Ukraina, której bliska korelacja z Republiką Federalną Niemiec zagrozi realizacji Polskich interesów, czego zalążki możemy obserwować w negocjacyjnym formacie normandzkim, który wypchnął Polskę poza grono państw aktywnie uczestniczących w rozwiązywaniu kryzysu ukraińskiego. Przyjazne, sąsiedzkie stosunki bilateralne między ośrodkami władzy, lecz co bardziej istotne - między historycznie bliskimi sobie narodami - będą bezsprzecznie stanowić podstawę realizacji zarówno polskich, jak i ukraińskich interesów. Budowa dobrosąsiedzkiej atmosfery wspólnego zaufania z całą pewnością nie może odbywać się za wszelką cenę, m.in. cenę wartości moralnych oraz nie powinna być oparta na przemilczeniu lub negacji prawdy historycznej. Kwestią niezwykle drażliwą, dzielącą oba narody, jest pamięć historyczna i antagonizmy narosłe w skutek tragicznych przeżyć zapisanych w dziejach obu społeczeństw. Problemem wyróżniającym się tutaj jest niewątpliwie Rzeź Wołyńska. Wspomniane wcześniej partykularne cele obu narodów nie będą mogły być jednak zrealizowane w sytuacji, kiedy antagonizmy narosłe na kanwie historii będą ciągle żywe. W tym też sensie w interesie zarówno Polski, jak i Ukrainy powinno leżeć wzajemne pochylenie się nad kwestią Rzezi Wołyńskiej i bilateralną historią w ogóle.

W okolicznościach kryzysu ukraińskiego wspierająca Kijów Warszawa stanęła przed dylematem, którego przedmiotem był kształt polityki zagranicznej zarówno wobec Rosji, jak i Ukrainy. W kontekście Rzezi Wołyńskiej mianem polskiej racji stanu, zgodnie ze stanowiskiem autora, należy określić kwestie pobudzenia w społeczeństwie ukraińskim samej świadomości Rzezi Wołyńskiej, zaprzestania jawnej gloryfikacji struktur i osób za nią odpowiedzialnych oraz przypisanie odpowiedzialności za popełnione czyny organizacjom, które się ich dopuściły. Ze względu na fakt, że działalność Federacji Rosyjskiej uznawana jest w Polsce za jedno z podstawowych źródeł zagrożenia, czego przyczyn można doszukiwać się m.in. w doświadczeniu historycznym i obawach przed współcześnie prowadzoną polityką Moskwy, kwestia realizacji polskiej raison d'État odnośnie do ludobójstwa Rzezi Wołyńskiej znalazła się w niezwykle skomplikowanym położeniu między tytułową rosyjską propagandą a ukraińskim poszukiwaniem tożsamości narodowej. Opisane wcześniej zagadnienia obrazują niezwykle wysoki poziom skomplikowania problemu. Warszawa wspierając Kijów, nie chce wpisywać się w stygmatyzującą Ukrainę retorykę Kremla oraz dawać Rosji pretekstu do użycia jakichkolwiek narzędzi (wypowiedzi, depesz, aktów prawnych) do realizacji partykularnych celów moskiewskiej propagandy.

Strategia obrana przez rząd Platformy Obywatelskiej i prezydenta Bronisława Komorowskiego, opierająca się na pragmatyzmie rozumianym jako wspieranie - lub może lepiej: nieprzeszkadzanie Ukrainie w jej konflikcie z Rosją poprzez ig-

${ }^{40}$ B. Grott, Polityka polska wobec Ukraińców, Ukrainy i ukraińskiego nacjonalizmu, [w:] Nacjonalizmy różnych narodów. Perspektywa politologiczno-religioznawcza, red. B. Grott, O. Grott, Kraków 2012, s. 111. 
norowanie aktów gloryfikacji zbrodniczych wobec narodu polskiego organizacji, miała m.in. związek z poczuciem bezpośredniego zagrożenia ze strony rosyjskiej. „Nie ma wolnej Europy bez wolnej Ukrainy” tweetował 24 sierpnia 2014 r. premier Donald Tusk ${ }^{41}$. Podejście takie, ze względu na różnice między zapędami imperializmu rosyjskiego a roszczeniami nacjonalizmu ukraińskiego, wydaje się być usprawiedliwione, a przynajmniej trzymające się spójnej logiki, przede wszystkim ze względu na nieporównywalne potencjały obu państw. Całkowity brak reakcji rządu polskiego na kolejne kroki podejmowane przez Kijów, jawnie gloryfikujące OUN i UPA, doprowadził w konsekwencji do zachowań bezpośrednio godzących w interes narodowy. Uchwalenie przez ukraiński parlament analizowanej wyżej ustawy o numerze 2538-1 w dniu wizyty prezydenta Bronisława Komorowskiego na Ukrainie, a jednocześnie w kilka godzin po jego wystąpieniu w Werchownej Radzie, pozwala na interpretowanie zachowań Kijowa jako zupełnie lekceważących stanowisko Warszawy lub, jeżeli zachowanie to było intuicyjne, wręcz jako działań mających na celu sprawdzenie, jak daleko sięgają granice tolerancji polskiego rządu. Oba warianty pozwalają natomiast na interpretację pozycji Polski pośród państw bezpośrednio i pośrednio uwikłanych w kryzys ukraiński i postrzeganie jej jako podmiotu nieposiadającego realnej mocy sprawczej, którego potencjalnie krytyczne stanowisko nie będzie związane z groźnymi z perspektywy Kijowa konsekwencjami. W oparciu o metodę analizy decyzyjnej następny brak dyplomatycznej reakcji należy rozpatrywać w kontekście polskiej polityki wewnętrznej i aktualnej ówcześnie perspektywy zbliżających się wyborów prezydenckich. Ponieważ kampania wizerunkowa Bronisława Komorowskiego opierała się na akcentowaniu spraw związanych $\mathrm{z}$ bezpieczeństwem, zaangażowaniem Polski w pomoc Ukrainie i dobrych relacjach bilateralnych między oboma państwami, jakiekolwiek zaburzenie tego wizerunku zadziałałoby na niekorzyść kandydata. Pozwala to na wyciągnięcie wniosku o przedkładaniu własnego interesu politycznego nad interes narodowy Rzeczpospolitej Polskiej.

Stabilizacja wewnętrznego systemu politycznego Ukrainy i marginalizacja radykalnych ugrupowań, takich jak Prawy Sektor, Ogólnoukraińskie Zjednoczenie „Svoboda” oraz Partia Radykalna Ołeha Laszki, które opowiadają się za rewizją granic, również z Polską ${ }^{42}$, lub jak w przypadku Ołeha Laszki mają bliskie powiązania $\mathrm{z}$ ochotniczymi batalionami neonazistowskimi walczącymi na wschodzie

${ }^{41}$ D. Tusk, Nemaye vilnoyi Yevropy bez nezalezhnoyi Ukrayiny. Mnohaya i blahaya lita ukrayins'komu narodovi z Dnem Nezalezhnosti!, 24.08.2014, https://twitter.com/donaldtusk/status/503444091200634880 (dostęp: 10 sierpnia 2015).

${ }^{42}$ Gazeta.pl, Wiec we Lwowie: „Odłaczyć ukraińskie ziemie od Polski!”, 22.01.2011, http://m.wiadomosci.gazeta.pl/wiadomosci/1,117915,8989900,Wiec_we_Lwowie_-_Odlaczyc_ukrainskie_ ziemie_od_Polski__.html (dostęp: 10 sierpnia 2015); Wprost.pl, „Przemyśl i kilkanaście powiatów powinny wrócić do Ukrainy", 1.30.2014, http://www.wprost.pl/ar/434318/Przemysl-i-kilkanascie-powiatow-powinny-wrocic-do-Ukrainy/ (dostęp: 10 sierpnia 2015). 
Ukrainy ${ }^{43}$, leżą w żywotnym interesie Warszawy. Ponadto ekstremistyczne metody działania zmilitaryzowanego ugrupowania, jakim jest Prawy Sektor, niosą obawy o bezpieczeństwo w bezpośrednim sąsiedztwie granic RP, czego przykładem może być lipcowe zajście w Mukaczewie ${ }^{44}$.

Jak poinformował Polski Instytut Pamięci Narodowej w listopadzie 2015 r., po kilku latach przerwy została wznowiona współpraca historyków w ramach Polsko-Ukraińskiego Forum Historyków, obejmującego swoim zakresem lata 1939-1947. Zgodnie z założeniem spotkania mają się odbywać dwa razy do roku, a efekty prac mających charakter konferencji będą publikowane na stronach internetowych polskiego i ukraińskiego IPNu. W grudniu 2015 r., przy okazji wizyty dyplomatycznej na Ukrainie prezydenta Andrzeja Dudy, któremu towarzyszył prezes Polskiego IPNu, dr Łukasz Kamiński, portal Istoriczna Prawda opublikował tekst zastępcy prezesa IPN, dr Pawła Dukielskiego, Polska-Ukraina-Historia. Forum dążenia do prawdy, w którym autor odniósł się do wznowionej inicjatywy Forum Historyków i kwestii Rzezi Wołyńskiej słowami: „To dobry początek. Naukowcy mają wspólny język, jakim są narzędzia badawcze do ustalenia faktów. Ustalenia historyków mogą stanowić pierwszy, bardzo ważny krok do pojednania, mogą go ułatwić przedstawiając fakty. Jednak pojednanie to wielki proces społeczny, który musi się zmierzyć z poczuciem krzywdy ofiar" ${ }^{\text {"45 }}$.

Jak wynika z poczynionej analizy, prowadzenie skutecznej polityki historycznej, uwzględniającej kwestię Rzezi Wołyńskiej, w obliczu trwającego konfliktu ukraińsko-rosyjskiego, jest zadaniem niezwykle problematycznym. Z pewnością całkowite ignorowanie poczynań Kijowa nie jest w zgodzie ani z polską racją sta$\mathrm{nu}$, ani nie jest korzystne dla relacji polsko-ukraińskich, albowiem tylko prawda historyczna i wspólne pochylenie się nad trudnymi kartami historii może doprowadzić do realnie partnerskich stosunków. Oczywiście silne naciski na Kijów nie doprowadzą do poprawy relacji polsko-ukraińskich, ale akcentowanie metodami dyplomatycznymi polskiego punktu widzenia i zaprzestanie bezrefleksyjnego przyjmowania polityki historycznej Kijowa są środkami, które mogą zostać skutecznie wprowadzone bez szkody dla bilateralnych kontaktów. Należy również zaznaczyć, że budowa tożsamości narodowej na bazie ruchów nazistowskich nie jest $\mathrm{w}$ perspektywie długoterminowej dla Ukrainy korzystna, zwłaszcza z uwagi na europejskie aspiracje kraju i chęć nawiązania partnerskich stosunków z sąsiadami.

${ }^{43}$ Mowa tu o neonazistowskim batalionie AZOV, oskarżanym również o zbrodnie wojenne. Wzmianka o jego profilu ideologicznym: M. Ogdowski, Małe wojny, „Polska Zbrojna” 2015 (wrzesień), nr 9 (833), s. 92-96.

${ }_{44}$ T. Iwański, P. Grochowski, Zajazd na Mukaczewo przejawem słabości systemowej Ukrainy, OSW, 15.07.2015, http://www.osw.waw.pl/pl/publikacje/analizy/2015-07-15/zajazd-na-mukaczewo-przejawem-slabosci-systemowej-ukrainy (dostęp: 10 sierpnia 2015).

${ }^{45}$ Instytut Pamięci Narodowej, Post Facebook, 14.12.2015, https://www.facebook.com/instytutpamiecinarodowej/posts/10156396142520245:0 (dostęp: 30 grudnia 2015). 


\section{Podsumowanie}

Kwestia Rzezi Wołyńskiej stała się niezwykle istotnym elementem kryzysu ukraińskiego. Jej specyfika jest związana $\mathrm{z}$ zaangażowaniem trzech uczestników stosunków międzynarodowych, z których każdy w sposób pośredni lub bezpośredni nawiązuje do tego niezwykle dotkliwego epizodu w celu realizacji swojej partykularnej strategii. Czy to nastawionej na wymierny interes, czy jak w przypadku Polski - związanej z dążeniem do prawdy i sprawiedliwości historycznej. O złożoności problemu świadczą również sprzeczne ze sobą priorytety międzypaństwowe i wewnątrzpaństwowe (polski dylemat: stabilna Ukraina czy prawda historyczna). $Z$ całą pewnością rozwiązanie tego problemu nie jest kwestią miesięcy, a być może nawet i lat oraz jest uzależnione od stabilności Ukrainy i regionu i dobrej woli ze strony ośrodków przede wszystkim w Kijowie i Warszawie. Nacjonalizm ukraiński odegrał znaczącą rolę podczas rewolucji Euromajdanu i niebezzasadne jest twierdzenie, że jako jego najbardziej radykalny odłam przyczynił się do zmiany reżimu politycznego. Niestety akceptacja pewnego rodzaju samowoli organizacji radykalnych przyczynia się do destabilizacji wewnętrznej kraju, czego przykładem może być zajazd na Mukaczewo z lipca 2015 r. czy niekontrolowana działalność batalionów ochotniczych na wschodzie kraju. Władze Ukrainy, budując nową tożsamość ukraińską na podstawach walki narodowowyzwoleńczej okresu II wojny światowej, poczyniły śmiały krok, narażając się zarówno na ataki propagandowe ze strony Kremla, jak i utrudniając sobie drogę do Unii Europejskiej. Obrana przez Kijów strategia stoi w jawnej sprzeczności z polską racją stanu zakładającą akceptację i potwierdzenie przez elity i społeczeństwo Ukrainy prawdy historycznej o ludobójczym charakterze działalności ukraińskich nacjonalistów. Realizacja polskich postulatów jest zadaniem niezwykle pracochłonnym, wynikającym ze złożoności samego problemu, diametralnie różnych wizji historii reprezentowanych przez narody ukraiński i polski oraz skomplikowanej sytuacji międzynarodowej. Ich realizacja będzie zależała przede wszystkim od umiejętności polskich ośrodków władzy i woli ukraińskiego reżimu.

Artykuł ukończono w grudniu 2015 r.

\section{Bibliografia}

Agencja Bezpieczeństwa Wewnętrznego, Raport z działalności Agencji Bezpieczeństwa Wewnętrznego $w$ 2014r., Warszawa 2015, http://www.abw.gov.pl/pl/pobierz/raporty/575, Raporty.html.

Babiak Mat, Poroshenko: 'UPA are heroes', will consider giving veteran legal status, Euromaidan Press, 26.09.2014, http://euromaidanpress.com/2014/09/26/poroshenko-to-consider-giving-upaveterans-legal-status/.

Вести.Ru, на Майдане работали снайперы “Правого сектора”, 30.03.2014, http://www.vesti.ru/ doc.html?id=1426836.

Engdahl W., US, EU meddling in Ukraine battle, RT.com, 30.01.2014, http://www.rt.com/op-edge/ us-eu-interference-in-ukraine-402/. 
European Parliament, European Parliament resolution of 25 February 2010 on the situation in Ukraine, 25.02.2010, http://www.europarl.europa.eu/sides/getDoc.do?pubRef=-//EP//TEXT+ $\mathrm{TA}+\mathrm{P} 7-\mathrm{TA}-2010-0035+0+\mathrm{DOC}+\mathrm{XML}+\mathrm{V} 0 / / \mathrm{EN}$.

Gazeta.pl, Wiec we Lwowie: 'Odłaczyć ukraińskie ziemie od Polski!', 22.01.2011, http://m.wiadomosci.gazeta.pl/wiadomosci/1,117915,8989900,Wiec_we_Lwowie_-_Odlaczyc_ukrainskie_ziemie_od_Polski__.html.

Grott B., Polityka polska wobec Ukraińców, Ukrainy i ukraińskiego nacjonalizmu, [w:] Nacjonalizmy różnych narodów. Perspektywa politologiczno-religioznawcza, red. B. Grott, O. Grott, Kraków 2012.

Hrycak J., Jeszcze raz o stosunku Ukraińców do Polaków ( $z$ Rosja w tle), [w:] idem, Nowa Ukraina. Nowe Interpretacje, Wrocław 2009.

Instytut Pamięci Narodowej, Post Facebook, 14.12.2015, https://www.facebook.com/instytutpamiecinarodowej/posts/10156396142520245:0.

Iwański T., Grochowski P., Zajazd na Mukaczewo przejawem słabości systemowej Ukrainy, OSW, 15.07.2015, http://www.osw.waw.pl/pl/publikacje/analizy/2015-07-15/zajazd-na-mukaczewo-przejawem-slabosci-systemowej-ukrainy.

Kanał Youtube Николай Фадеев, Рада почтила минутой молчания Шухевича, https://www. youtube.com/watch? $\mathrm{v}=\mathrm{LObfl} 9 \mathrm{QSbOw}$.

KIIS, SOCIO-POLITICAL SITUATION IN UKRAINE: JULY 2015, 20.07.2015, http://www.kiis. com.ua/?lang=eng\&cat=reports\&id=540\&page $=1$.

KIIS, SOCIO-POLITICAL SITUATION IN UKRAINE: SEPTEMBER 2015, 5.10.2015, http://www. kiis.com.ua/?lang=eng\&cat=reports\&id $=548 \&$ page $=1$.

Kotowska B., Kandydat na prezydenta Andrzej Duda w TV Republika "nie boję się wyzwañ", 14.05.2015, https://www.youtube.com/watch?t=435\&v=jAkaIHTZ1Ko.

Mucha W., Krew i Ziemia. O ukraińskiej rewolucji, Warszawa 2014.

Novorossia Today, Fighting against Neo-Nazism one of Russia's foreign policy priorities - diplomat, 10.07.2015, http://novorossia.today/fighting-against-neo-nazism-one-of-russia-s-foreign-policy-priorities-diplomat/.

Ogdowski M., Małe wojny, „Polska Zbrojna” 2015 (wrzesień), nr 9 (833).

Olszański T.A., Koniec reżimu Janukowycza, OSW, 26.02.2014, http://www.osw.waw.pl/pl/publikacje/analizy/2014-02-26/koniec-rezimu-janukowycza.

Olszański T.A., Nowy rząd Ukrainy: stabilizacja mimo przeszkód, OSW, 5.03.2014, http://www.osw. waw.pl/pl/publikacje/analizy/2014-03-05/nowy-rzad-ukrainy-stabilizacja-mimo-przeszkod.

Olszański T.A., Ukraina: ambitne ustawy dekomunizacyjne, OSW, 15.04.2015, http://www.osw. waw.pl/pl/publikacje/analizy/2015-04-15/ukraina-ambitne-ustawy-dekomunizacyjne.

PolskieRadio.pl, Kijów ustanawia Dzień Obrońcy Ukrainy w dniu święta UPA. Putin oburzony, 14.10.2014, http://www.polskieradio.pl/5/3/Artykul/1258963,Kijow-ustanawia-Dzien-Obroncy-Ukrainy-w-dniu-swieta-UPA-Putin-oburzony.

Portal Telewizji Republika, Republika na żywo - Paweł Kukiz, 18.02.2015, https://www.youtube. com/watch?v=L0LQbfLbO4E.

Rigamonti M., Ze mnie dupa nie polityk, Wywiad z gen. Waldemarem Skrzypczakiem, „Dziennik Gazeta Prawna", 17.10.2015, nr 74 (3967).

RussiaToday.com, Dozens hurt and arrested after Ukrainian nationalists attack parliament, 12.10.2014, http://www.rt.com/news/195796-nationalists-protest-kiev-ukraine/.

RussiaToday.com, History lesson? Poroshenko says 'Hitler \& Stalin started WWII, wanted to divide Europe', 10.04.2015, http://www.rt.com/news/248409-poroshenko-wwii-stalin-hitler/.

RussiaToday.com, Polish general 'calls back support' of Ukraine over nationalist glorification, 18.10.2015, http://www.rt.com/news/250905-polish-general-rejects-ukrane/.

RussiaToday.com, Protesters topple Lenin monument in Kiev, smash to pieces with hammers, 8.12.2013, http://www.rt.com/news/ukraine-protesters-smash-lenin-913/. 
RussiaToday.com, 'Result of Maidan - revival of Nazism in Ukraine', 10.04.2015, http://www. rt.com/op-edge/248497-ukraine-law-fascists-nazi-ww2/.

RussiaToday.com, Кандидат в президенты Польши Павел Кукиз заявил, что нельзя поддерживать героизирующих Бандеру, 18.02.2015, http://russian.rt.com/article/75112.

Tusk D., Nemaye vilnoyi Yevropy bez nezalezhnoyi Ukrayiny. Mnohaya i blahaya lita ukrayins'komu narodovi z Dnem Nezalezhnosti!, 24.08.2014, https://twitter.com/donaldtusk/ status/503444091200634880.

Wężyk K., Kresy. Dla nas piekło, dla was raj. Rozmowa z Jarosławem Hrycakiem, 25.07.2015, http://wyborcza.pl/magazyn/1,147225,18418145,kresy-dla-nas-pieklo-dla-was-raj-rozmowaz-jaroslawem.html.

Wierzbicka-Miazga A., Rosja chce zablokować możliwość dialogu Janukowycza z zachodem, OSW, 11.12.2013, http://www.osw.waw.pl/pl/publikacje/analizy/2013-12-11/rosja-chce-zablokowac-mozliwosc-dialogu-janukowycza-z-zachodem.

Wprost.pl, „Przemyśl i kilkanaście powiatów powinny wrócić do Ukrainy”, 1.30.2014, http://www. wprost.pl/ar/434318/Przemysl-i-kilkanascie-powiatow-powinny-wrocic-do-Ukrainy/.

Канашевич С., Госдума приняла законопроект о запрете бандеровской символики, 21.10.2014, http://top.rbc.ru/politics/21/10/2014/54466850cbb20f85ef0a05ac.

Сич Олександр, Post Facebook, 13.10.2015, https://www.facebook.com/sych.olexander/posts/102 08340991381816?pnref=story.

Украинская правда, Яценюк о Бандере: это наши герои, 6.11.2012, http://www.pravda.com.ua/ rus/news/2012/11/6/6976794/. 